\title{
Clinical Comparison of Percutaneous and Open Hamstring Lengthening in Children with Spastic Cerebral Palsy
}

\author{
Spastik Serebral Palsili Hastalarda Uygulanan Perkütan ve Açık \\ Hamstring Uzatmanın Klinik Kıyaslaması
}

\author{
Yalcın TURHAN $\odot$, Mehmet ARICAN $\odot$
}

Ethics Committee Approval: This study approved by the Duzce University Clinical Studies Ethic Committee, 17 December 2018, 2018/227.

Conflict of interest: The authors declare that they have no conflict of interest.

Funding: None.

Informed Consent: Informed consent was taken from the parents of the patients enrolled in this study.

\begin{abstract}
Objective: Knee flexion contracture due to increased hamstring muscle spasticity is the most commonly seen knee deformity in patients with cerebral palsy (CP) and hamstring lengthening is a useful technique for this problem. The purpose of this study is to evaluate the clinical outcomes of open (OHL) vs. percutaneous hamstring lengthening (PHL) surgery.

Method: This retrospective study was performed on medical files of spastic cerebral palsy patients who underwent open or closed hamstring lenghtening surgery because of knee flexion contracture between the years 2014 and 2018. All surgical procedures were carried out under general anesthesia and the patients' preoperative and postoperative popliteal angles (PA) were recorded. In $\mathrm{OHL}$, one midline incision was used to lengthen the medial and lateral hamstrings. In PHL, both the medial and lateral hamstrings were lengthened percutaneously by a no. 15 blade.

Results: Twenty-six knees of 17 patients were included in the study. Mean age of the patients was 10.6 (6-17) years. Nine patients with 14 knees were included in $\mathrm{OHL}$ and 8 patients with 12 knees in PHL group. Mean preoperative popliteal angle (PA) was $45^{\circ}( \pm 6.03)$ and decreased to $24^{\circ}( \pm 4.37)$ after the $O H L$ procedure $(p=0.0001)$. Mean preoperative $P A$ was $49.75^{\circ}( \pm 6.7)$ and decreased to $26^{\circ}( \pm 7.12)$ after the PHL procedure $(p=0.0001)$. There was no statistically significant difference in terms of the mean differences between the preoperative and postoperative $P A$ in $O H L$ and $P H L$ groups $(p=0.215)$.

Conclusion: The findings of this study have shown that the relatively simple and minimal invasive PHL technique can be considered a viable option in selected patient groups for hamstring lengthening.
\end{abstract}

Keywords: Cerebral palsy, hamstring spasticity, percutaneous hamstring lengthening, popliteal angle öz

Amaç: Serebral palsili hastalarda gözlenen artmış hamstring kas gerginliği diz fleksiyon kontraktürünün en sık rastlanan nedenidir ve hamstring uzatma cerrahisi bu sorun için uygulanan yararlı bir yöntemdir. Bu çalışmada, açık ya da perkütan yöntemle uygulanan hamstring uzatma cerrahisi klinik sonuçlarının değerlendirilmesi amaçlanmıştır.

Yöntem: Geriye dönük hasta kayıtları üzerinden yapılan bu calısmada, 2014-2018 yılları arasında diz fleksiyon kontraktürü nedeniyle açık ya da kapalı yöntemle hamstring uzatma cerrahisi uygulanan srebral palsili hastalar incelenmiştir. Tüm cerrahi müdahaleler genel anestezi altında yapılmış ve hastaların preoperatif ve postoperatif popliteal açıları (PA) kaydedilmiştir. Açı teknikte medial ve lateral hamstring kaslarını uzatmak icin tek bir orta hat insizyonu kullanılmıstır. Perkütan teknikte ise medial ve lateral hamstring kasları 15 numara bistüri yardımıyla perkütan olarak uzatılmıştır.

Bulgular: Calıșmaya 17 hastanın 26 dizi dahil edildi. Hastaların ortalama yașı 10.6 (6-17) idi. Aclk cerrahi uygulanan grupta 9 hasta (14 diz), perkütan cerrahi uygulanan grupta ise 8 hasta (12 diz) mevcut idi. Açlk cerrahi sonucunda preoperatif ortalama $45^{\circ}( \pm 6,03)$ olan popliteal açı postoperatif $24^{\circ}( \pm 4,37)$ 'ye geriledi $(p=0.0001)$. Perkütan teknik uygulanan grupta ise ortalama popliteal aç $49,75^{\circ}( \pm 6,7)$ 'ten $26^{\circ}( \pm 7,12)$ 'ye geriledi $(p=0.0001)$. Gruplar arasında preoperatif ve postoperatif popliteal açı değișimleri acısından anlamlı farklıık saptanmadı $(p=0.215)$.

Sonuç: Bu çalışmanın bulguları, nispeten basit ve minimal invazif bir teknik olan perkütan hamstring uzatma cerrahisinin seçilmiş hasta gruplarında uygun bir seçenek olarak kabul edilebileceğini göstermiştir.

Anahtar kelimeler: Serebral palsi, hamstring gerginliği, perkütan hamstring uzatma, popliteal açı
Received: 10.02 .2019

Accepted: 25.04.2019

Online First: 10.06 .2019

Corresponding Author: Y. Turhan

ORCID: 0000-0002-1440-9566

Duzce University Medical Faculty, of Orthopaedics and Traumatology, Department Duzce - Turkey

yturhan_2000@yahoo.com

M. Arican

ORCID: 0000-0002-0649-2339 Duzce University Medical Faculty, of Orthopaedics and Traumatology, Department Duzce, Turkey 


\section{INTRODUCTION}

Children with spastic cerebral palsy (CP) have a common risk to acquire bony deformities due to joint contractures. With some management modalities applied before these bony deformities had developed, the unwanted persistent disabilities could be overcome ${ }^{1,2}$. Operative treatment is generally needed in most of the children with spastic CP and the surgical managements should be postponed up to the age of 6-7 to wait for the child's natural gait cycle ${ }^{3}$. The most commonly encountered knee deformity in spastic CP is the knee flexion contracture owing to hamstring muscle spasticity ${ }^{2}$. Surgical lengthening of hamstring muscles is performed to prevent development of knee flexion contracture. The targeted muscles for surgical treatment are medial (semitendinosus, semimembranosus) and lateral hamstring (biceps femoris). muscles.

Hamstring lengthening procedures can be applied as aponeurotic and z-lengthening or as simple tenotomy ${ }^{4-7}$, also the procedures can be done using either open (OHL) or percutaneous (PHL) techniques $^{8,9}$. PHL is a minimally invasive procedure and has a potential to cause less internal (less fibrous tissue formation around lengthened tendon) and external scarring ${ }^{10}$. Aside its advantages, there is an increased risk of injuring the popliteal vessels or sciatic nerve. Although a precise and clear description of OHL can be found in the literature, it is difficult to say the same thing for $\mathrm{PHL}^{11}$. The two types of PHL procedures reported in the literature are distal complete tenotomy of both tendons and myofascial lengthening at the muscle-tendon junction ${ }^{12,13}$.

It can be thought that PHL technique is as effective as OHL in the treatment of hamstring spasticity. The aim of this retrospective study was to evaluate the functional results of OHL vs. PHL in the treatment of hamstring spasticity in children with spastic CP.

\section{MATERIAL and METHODS}

This study approved by the Duzce University Clinical Studies Ethic Committee, 17 December 2018, 2018/227.

\section{Subjects}

All the patients with spastic $\mathrm{CP}$ who underwent hamstring lengthening by either OHL or PHL under general anesthesia in our clinics from 2014 to 2018 were evaluated retrospectively. Informed consent was taken from the parents of the patients enrolled in this study. Patients were 6-18 years old and had isolated knee flexion contractures with increased popliteal angles (PA). The inclusion criteria of this study are summarized in table 1. Patients with achilles tendon or hip flexor spasticity and patients who cannot walk were excluded from the study.

Table 1. Inclusion criteria of the study.

Inclusion criteria
Patients with spastic CP
Between the ages of $6-18$
Isolated hamstring spasticity
Without any bony deformities
Without any previous hamstring surgeries
With more than $30^{\circ}$ of PA under general anesthesia

\section{Preoperative evaluation}

The patients were examined under general anesthesia for the preoperative PA measurements. The PA was evaluated with the patient laid in supine position with the examined extremity at an angle of $90^{\circ}$ to hip and its knee at flexion while the contralateral extremity in full extension. The PA is represented by the angle between the examined leg and the vertical line through the ipsilateral femur in maximum extension of the knee measured with a $1^{\circ}$ calibrated goniometer (Figure 1). The maximum extension means the ending of extension when pelvic rotation initiates ${ }^{14}$. After the measurements, patients underwent either OHL or PHL. 


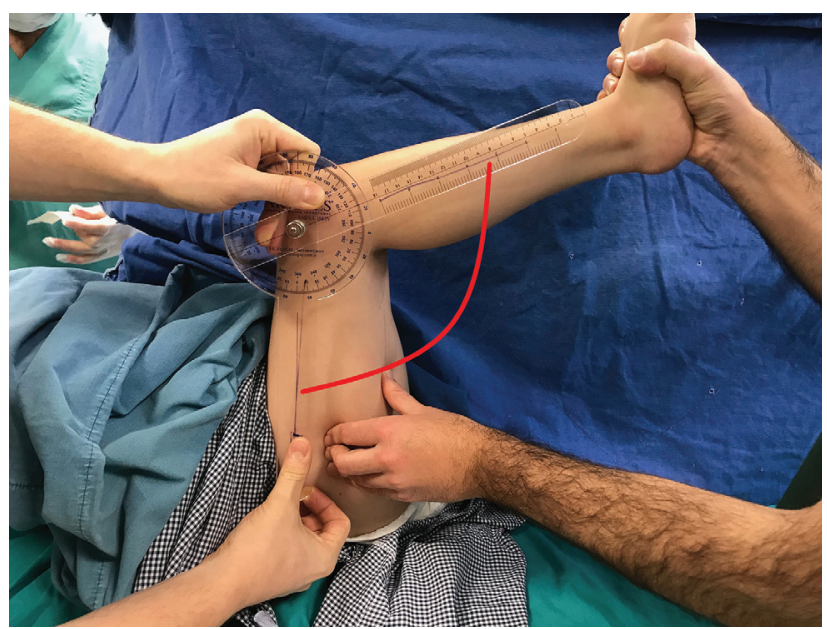

Figure 1. Intraoperative measurement of popliteal angle by $1^{\circ}$ calibrated goniometer. The angle is formed by the vertical axis of the femur and the axis of tibia.

\section{Surgical procedures}

All patients were operated under general anesthesia in the supine position without tourniquet

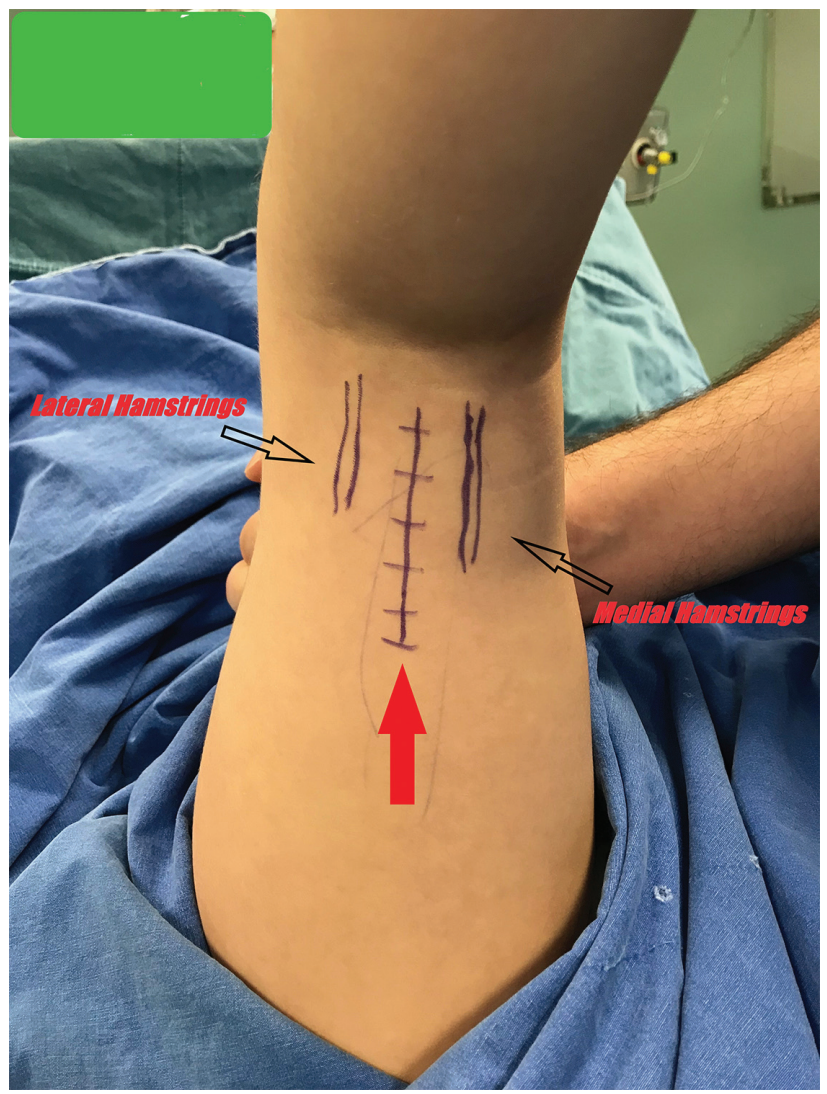

Figure 2. The midline incision for the open hamstring lengthening (red arrow) and traces of medial and lateral hamstring muscle groups (Right lower extremity; hip is flexed $90^{\circ}$ and the knee joint is in maximum extension). application. The patients were randomly selected for open or percutaneous surgery.

In OHL; a $7 \mathrm{~cm}$ posterior midline incision starting just proximal to the popliteal crease was made (Figure 2). First of all, the semitendinosus was z-lengthened and then fractional lengthening of semimembranosus muscle was made by 2 or 3 transverse incisions over its fascia. Then PA measurement was repeated and in cases with more than $30^{\circ}$ of PA, fractional aponeurotic lengthening of biceps femoris was also performed.

In PHL; the technique described by Kay RM was used $^{15}$. The medial and lateral hamstring muscles were palpated with the knee in passive extension (Figure 3). The semitendinosus muscle was identified just proximal to its musculotendino-

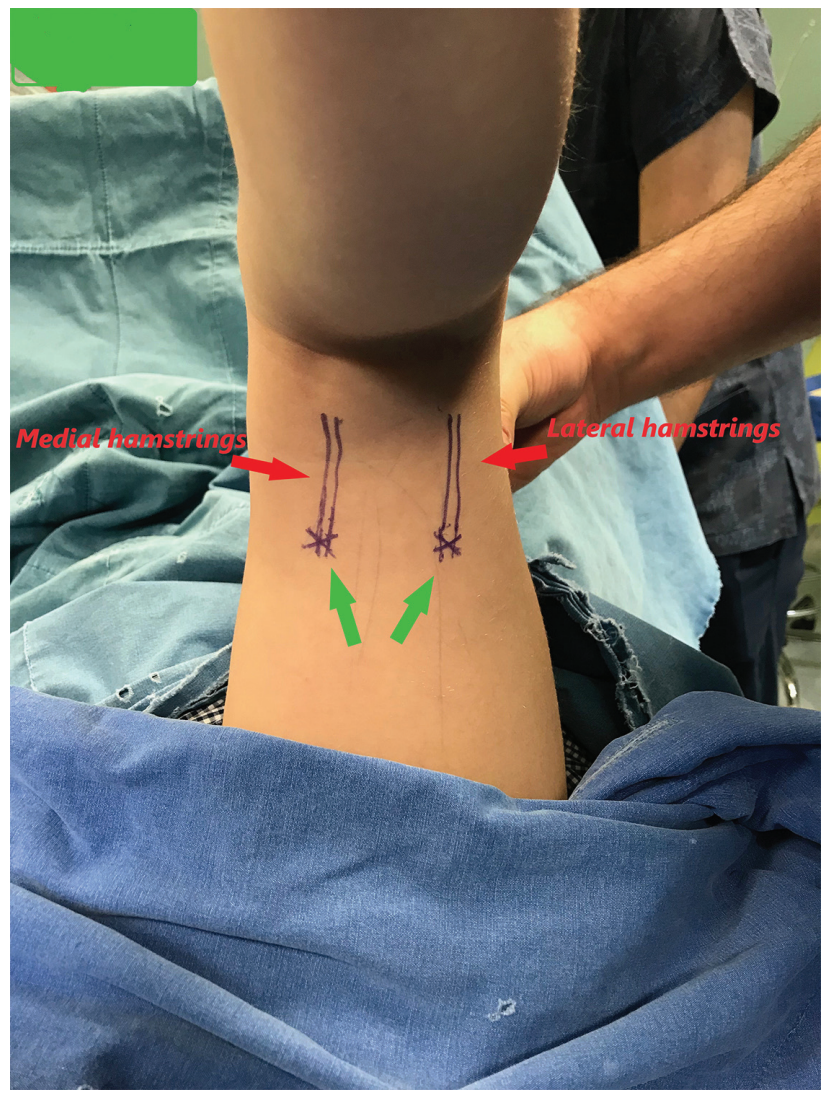

Figure 3. The traces of medial and lateral hamstring muscle groups and the entry points of surgical blades for percutaneous hamstring lengthening (green arrows) (Left lower extremity; hip is flexed $90^{\circ}$ and the knee joint is in maximum extension). 
us junction; with a no. 15 surgical blade a cut is made directly lateral and anterior to the tendon and then extended medially and parallel to thigh. Afterwards the blade was turned $90^{\circ}$ upward to make a transverse cut in the fascia, and then turned $90^{\circ}$ in the opposite direction, and removed form the surgical site. If the semimembranosus muscle is also tight, then a no. 15 blade is used to perform to lengthen this muscle through the same incision. Then PA measurement was repeated as in OHL; and if necessary, biceps femoris muscle was lengthened; and a second percutaneous incision was made with no. 15 blade just medial to its aponeurotic band and a single-level recession was made.

Recurrent postoperative PA measurements were made and recorded. Above-knee plaster cast was applied with knee in full extension in all patients for 3 weeks.

\section{Statistical analysis}

Number Cruncher Statistical System (NCSS) 2007 Statistical Software (Utah, USA) was used for statistical analyses. In addition to descriptive statistics, the paired t-test in the time comparisons of the variables with normal distribution, independent t-test for comparison of binary groups and chi-square test for comparison of qualitative data were used. A p-value of less than 0.05 was considered statistically significant.

\section{RESULTS}

A total of 17 patients (26 knees) with spastic CP having knee flexion contracture due to hamstring spasticity were treated either by OHL or PHL. Any accidental injuries to the surrounding neurovascular structures were encountered during, and after surgery in both of the groups. Mean age of the patients was 10.6 (6-17) years. The deformities were bilateral in diplegic patients and unilateral in hemiplegic ones. Nine patients (5 diplegic, and 4 hemiplegic patients) with 14 knees were present in OHL group ( 2 females and 7 males). Eight patients (4 diplegic and 4 hemiplegic patients) with 12 knees were present in PHL group (8 males) (Table 2). All of the patients had isolated hamstring spasticity previously treated with only physical therapy and had no history of any orthopedic surgery for affected lower extremities including tendon, muscle or joint surgeries.

There were no statistically significant differences between the groups in terms of mean age, gender and side distributions $(p=0.525, p=0.156$ and $\mathrm{p}=0.671$ accordingly). There was also no statistically significant difference in mean preoperative and postoperative PA values between the groups (p>0.05) (Table 2).

Mean preoperative PA was $45^{\circ}\left(35^{\circ}\right.$ to $\left.55^{\circ} \pm 6.03\right)$ and decreased to $24^{\circ}\left(18^{\circ}\right.$ to $\left.32^{\circ} \pm 4.37\right)$ after the

Table 2. Subject characteristics and statistical comparison of groups.

\begin{tabular}{|c|c|c|c|c|}
\hline & & OHL Group & PHL Group & $\mathbf{p}^{*}$ \\
\hline \multicolumn{2}{|l|}{ Age } & $10 \pm 4.5$ & $11.38 \pm 4.17$ & $0.525^{*}$ \\
\hline \multirow[t]{2}{*}{ Sex } & Male & $77.78 \%$ & $8 \quad 100.00 \%$ & \multirow[t]{2}{*}{$0.156+$} \\
\hline & Female & $22.22 \%$ & $0.00 \%$ & \\
\hline \multirow[t]{3}{*}{ Side } & Right & $50.00 \%$ & $41.67 \%$ & \multirow[t]{2}{*}{$0.671+$} \\
\hline & Left & $7 \quad 50.00 \%$ & $7 \quad 58.33 \%$ & \\
\hline & Preop & $45 \pm 6.03$ & $49.75 \pm 6.7$ & $0.069^{*}$ \\
\hline PA & Postop & $24 \pm 4.37$ & $26 \pm 7.12$ & $0.389^{*}$ \\
\hline \multicolumn{2}{|c|}{$\mathrm{p} \ddagger$} & 0,0001 & 0,0001 & \\
\hline \multicolumn{2}{|c|}{$\begin{array}{l}\text { Preoperative/Postoperative } \\
\text { difference in PA }\end{array}$} & $21 \pm 5.41$ & $23.75 \pm 5.59$ & $0.215^{*}$ \\
\hline
\end{tabular}

*Independent $t$ test, $\neq$ Matched $t$ test, + Chi-square test

OHL: Open hamstring lengthening, PHL: Percutaneous hamstring lengthening, PA: Popliteal angle 
OHL procedure $(p=0.0001)$. Mean preoperative PA was $49,75^{\circ}\left(36^{\circ}\right.$ to $\left.60^{\circ} \pm 6.7\right)$ and decreased to $26^{\circ}\left(18^{\circ}\right.$ to $\left.35^{\circ} \pm 7.12\right)$ after the PHL procedure $(p=0.0001)$. There was no statistically significant difference in terms of the mean differences between the preoperative and postoperative popliteal angles of OHL and PHL groups $(p=0.215)$ (Table 2).

\section{DISCUSSION}

Muscle and tendon contractures, bone and joint deformities are encountered very often in children with spastic CP in proportion with the level of spasticity. In the early period, flexion contractures develop in the joints due to flexor muscle spasticity ${ }^{16}$. Knee flexion contracture is one of the most common problems seen in spastic CP. Hamstring lengthening surgery is a useful technique in improving functions of these patients having ambulation potential ${ }^{17}$.

The lengthening surgery can be carried out either with open or percutaneous techniques. However, it is proposed to be done with open technique until the surgeon has gained experience with the anatomy and the feel of fractional tendon lengthenings ${ }^{15}$. The OHL was clearly described in previous studies whereas the PHL has not been defined specifically ${ }^{7,8}$. But the effectiveness and safety of percutaneous tendon lengthening procedures have been shown previously for various anatomical locations like Achilles tendon ${ }^{18,19}$. Also the effectiveness of PHL in improving gait parameters even in the long term was shown by Gordon et al. ${ }^{12}$. In their series, only the lengthening of semitendinosus muscle was performed by percutaneous technique and their series did not include any open surgical group as control for the purpose of comparison. In our study, both of the semitendinosus and semimembranosus muscles and also biceps femoris muscle in case of need were lengthened with PHL technique and all the surgeries were done by a single surgeon with sufficient experience about open tendon lengthenings.
In a recent prospective anatomical study showing the effectiveness and safety of PHL, undesirable extensive muscle injury was reported with this percutaneous technique ${ }^{11}$. Although any accidental injury to the surrounding structures and neurovascular complications with PHL surgery was reported, they did not recommend PHL instead of OHL because of the unexpected muscle injury and less gain in PA with PHL. In this present study, the gain in the PA was similar in both groups and also we had not encountered any damage neither in surrounding muscular nor neurovascular structures.

Recurvatum deformity has been reported as a potential complication after hamstring lengthening surgeries $^{7}$. This deformity is thought to be more common especially after PHL procedures due to unexpected damage to the tendons leading to persistent hamstring weakness. Besides, Kay et al. ${ }^{7}$ associated the postoperatively increased recurvatum deformity with spastic gastrocnemius muscle. In this study, we did not evaluate the postoperative recurvatum deformity in patients but all of them had isolated hamstring contracture and no one had gastrocnemius spasticity. In a recent study by Mansour et al. ${ }^{11}$, although unacceptable damage to the muscular portion of both medial hamstrings with percutaneous lengthening occurred, they did not encounter any correlation between the PA gain and development of recurvatum deformity

This study has some limitations like other retrospective studies with this group of patients. The patient population is small, postoperative followup is lacking and the patients were not evaluated according to the necessity of biceps tenotomy. The aim of this study, however, was to evaluate the efficacy of PHL in intraoperative correction of PA. The surgeries were done by a single surgeon and the patient population was homogenous including only the patients with spastic CP and isolated knee flexion contracture. 


\section{CONCLUSION}

The PHL had shown similar results with OHL performed for the hamstring lengthening in this homogenous patient population. Therefore, this minimally invasive and simple technique can be considered as a viable option in selected patient groups for hamstring lengthening.

\section{REFERENCES}

1. Arnold AS, Salinas S, Hakawa DJ, Delp SL. Accuracy of muscle moment arms estimated from MRI-based musculoskeletal models of the lower extremity. Comput Aid Surg. 2000;5:108-119. [CrossRef]

2. Horstmann HM, Bleck EE. Orthopaedic Management in Cerebral Palsy. $2^{\text {nd }}$ ed. London, Mac Keith Press, 2007: 303-43.

3. Koman LA, Smith BP, Barron R. Recurrence of equinus foot deformity in cerebral palsy patients following surgery: a review. J South Orthop Assoc. 2003;12:125-33.

4. Abel MF, Damiano DL, Pannunzio M, Bush J. Muscletendon surgery in diplegic cerebral palsy: functional and mechanical changes. J Pediatr Orthop. 1999;19:366-75. [CrossRef]

5. Baumann JU, Ruetsch H, Schurmann K. Distal hamstring lengthening in cerebral palsy: an evaluation by gait analysis. Int Orthop. 1980;3:305-9. [CrossRef]

6. Chang W-N, Tsirikos AI, Miller F et al. Distal hamstring lengthening in ambulatory children with cerebral palsy: primary versus revision procedures. Gait Posture. 2002;19:298-304. [CrossRef]

7. Kay RM, Rethlefsen SA, Skaggs D et al. Outcome of medial versus combined medial and lateral hamstring lengthening surgery in cerebral palsy. J Pediatr Orthop. 2002;22:169-72. [CrossRef]

8. Westwell M, Deluca P, Ounpuu S. Effect of repeat hamstring lengthenings in individuals with cerebral palsy. Dev Med Child Neurol. 2004;46:14-5.
9. Damron T, Breed AL, Roecker E. Hamstring tenotomies in cerebral palsy: long-term retrospective analysis. J Pediatr Orthop. 1991;11:514-9. [CrossRef]

10. Bishay SN. Short-term results of musculotendinous release for paralytic hip subluxation in children with spastic cerebral palsy. Ann R Coll Surg Engl. 2008;90:127-32. [CrossRef]

11. Mansour T, Derienne J, Daher M, et al. Is percutaneous medial hamstring myofascial lengthening as anatomically effective and safe as the open procedure? J Child Orthop. 2017;11:15-9. [CrossRef]

12. Gordon AB, Baird GO, McMulkin ML, et al. Gait analysis outcomes of percutaneous medial hamstring tenotomies in children with cerebral palsy. J Pediatr Orthop. 2008;28:324-9. [CrossRef]

13. Mitsiokapa EA, Mavrogenis AF, Skouteli H et al. Selective percutaneous myofascial lengthening of the lower extremities in children with spastic cerebral palsy. Clin Podiatr Med Surg. 2010;27:335-43. [CrossRef]

14. Rachkidi R, Ghanem I, Kalouche I, et al. Is visual estimation of passive range of motion in the pediatric lower limb valid and reliable. BMC musculoskelet Disord. 2009;10:126. [CrossRef]

15. Kay RM. Lower-extremity surgery in children with cerebral palsy. In: Master Techniques in Orthopaedic Surgery. Skaggs DL, Kocher MS (eds), $2^{\text {nd }}$ edition. Philadelphia, Wolters Kluwer, 2016: p. 149-92.

16. Browne AO, McManus F. One-session surgery for bilateral correction of lower limb deformities in spastic diplegia. J Pediatr Orthop. 1987;7:259-61. [CrossRef]

17. Ahmed AAY, Rafalla AAA. Clinical outcome of hamstring lengthening to correct flexed knee gait in patients with spastic diplegia. Egyptian Orthop J. 2016;51:352-8. [CrossRef]

18. Hoefnagels EM, Waites MD, Belkoff SM, Swierstra BA. Percutaneous Achilles tendon lengthening: a cadaverbased study of failure of the triple hemisection technique. Acta Orthop. 2007;78:808-12. [CrossRef]

19. Dobbs MB, Gordon JE, Walton T, Schoenecker PL. Bleeding complications following percutaneous tendo achilles tenotomy in the treatment of clubfoot deformity. J Pediat Orthop. 2004;24:353-7. [CrossRef] 